\title{
EXPRESSION OF MULTIMODAL LEARNING TO READ AND WRITE IN THE CONTEXT OF PRE-PRIMARY EDUCATION
}

\author{
Aldona Mazolevskienè, Ieva Pažusienè \\ Vytautas Magnus University, Education Academy, Lithuania
}

\begin{abstract}
Multimodal learning to read and write emphasises the transition from the conception of direct teaching/learning (ability to decode printed text written on the paper) to spontaneous and child-initiated learning in the playful environment, which would originate from the child's wish to learn, experience and know. Thus, multimodal learning refers to the learning, which employs as many and as diverse ways of education as possible. They aim to promote children's learning, memorising and comprehension, which most frequently manifest in children's positive emotions, new experiences, improvement of learning process and its adaptation to creation of child-centred education system and its realisation in practice. The changing attitude towards learning to read and write obviously leads to strengthening of the tradition of multimodal learning in the Lithuanian kindergartens. The working methods and means applied by teachers, which allow creating educational environments taking into consideration individual needs of every child environments, have been undergoing changes. The conducted research revealed that pre-primary education groups provide children with favourable conditions for multimodal learning, which helps them not only to learn to read and write faster but also develop other skills: fine motor skills, thinking, creativity, social skills, etc.
\end{abstract}

Keywords: learning, literacy, multimodal, reading, writing.

\section{Introduction}

Recent research studies on reading and writing of early age and pre-primary children have focused on understanding and revealing why some children learn to read and write easier than the others as well as to discover what is most effective while teaching children to read and to write (McGuinness, 2005). Up to now most of the conducted research has been based on the assumption that the concept reading is related mainly to the ability to decode the text printed on the paper. However, a big number of researchers and teachers have acknowledged that the essence of literacy has been considerably changing lately (Kitsiou \& Kondyli, 2020; 
Kress et al., 2014; Bearne, 2009). The researchers (Hassett \& Schieble, 2007) emphasise that a new level of text comprehension and meaning creation has been emerging in the process of learning. Theoretical insights allow for stating that in the process of child's learning to read and to write, the majority of teachers tend to focus on the direct teaching of children more (i. e., on ability to decode the printed text). However, spontaneous and child-initiated multimodal learning in the playful environment, which would derive from the child's wish to learn, experience and find out should be considered a more important objective.

Recently a variety of scientific approaches to the process of reading have been prevailing in Lithuania as well as in other countries all over the world. The understanding of reading skills development is modern and conceptually rich. Moreover, search for innovations, trends of diversity and renewal have been observed in the very practice of developing reading skills (Merkys et al., 2010). The changing attitude towards learning to read and to write obviously results in the traditions of multimodal learning in the Lithuanian kindergartens. The teaching methods and means applied by teachers have been undergoing changes. Teachers tend to establish stimulating environments taking into account individual needs of every child. Although the numbers of research studies on learning to read and write conducted in Lithuania (Baranova \& Duoblienè, 2020; Merkys et al., 2010; Gedutienè, 2008; Martinkienè, 2004) have been growing, research on multimodal learning in early childhood and pre-primary education has been scarce. For this reason, the present research aims to reveal the expression of learning to read and to write in pre-primary education because this is the period, when the child's reading and writing skills undergo the most intensive development. The currently important research and practical problem can be formulated as the following problem question.

How do teachers understand and apply multimodal learning to read and to write in pre-primary children's education?

The research goal - to disclose the expression of multimodal learning to read and to write in the context of pre-primary education. The research objectives: following the scholarly literature to determine the concept and peculiarities of multimodal learning to read and to write; to reveal the experience of pre-primary teachers in clarifying the expression of multimodal learning to read and to write.

\section{Methodology}

The research on multimodal learning to read and write was organised employing the qualitative research method, i. e., a semi-structured interview. The interview method allows identifying the informants' attitudes and 
opinions regarding the evaluated questions. While conducting the research, attempts were made to clarify the opinion of teachers-experts working in an early childhood education institution about to what extent expression of multimodal learning to read and write is spread in Lithuanian pre-primary education institutions. The sample of experts: 22 experts. The teachers with at least 5 years of experience in pre-primary education groups and responsible for expression of the process of children education were interviewed. The informants were selected applying the target group method.

The research tool. The questionnaire survey consisted of 7 questions, which were constructed as three diagnostic blocks: 1) a block of questions to identify how a child learns during multimodal learning; 2) a block of questions to identify what strategies, methods and ways are used by pre-primary teachers; 3) a block of questions to reveal the impact and benefit of multimodal learning. Applying the method of semi-structured interview, the data is accumulated in a form of verbatim texts. The content analysis and open coding method were applied for qualitative data analysis, i. e., the responses of informants were read several times and divided into separate groups according to the content of responses.

\section{Results}

According to Kress and colleagues (2014), during multimodal learning all the senses and experiences are engaged in the process of education seeking to increase activities of different parts of brains simultaneously. Thus, learners are provided with more ways to remember information and to retain it in their memory.

The respondents distinguished the most important learning components, which are reflected in the following four subcategories: senses, experience, exploration and play (Table 1).

Table 1. The components of multimodal learning

\begin{tabular}{|c|c|c|}
\hline Category & Subcategory & Justifying statements \\
\hline \multirow[t]{4}{*}{ Components } & Senses & $\begin{array}{l}\text { "Tracing over every letter, touching and } \\
\text { groping". }\end{array}$ \\
\hline & Experience & $\begin{array}{l}\text { " }<\ldots>\text { experiences and then lives through it } \\
\text { himself or herself". }\end{array}$ \\
\hline & Exploration & $\begin{array}{l}\text { " }<\ldots>\text { encourages curiosity, evokes their } \\
\text { interest and wish to explore". }\end{array}$ \\
\hline & Play & 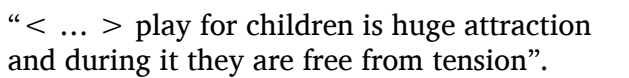 \\
\hline
\end{tabular}


Martinkienè (2004) states that while learning to read and to write in pre-primary education the methods that promote communication and collaboration, active learning, critical thinking and creativity are most frequently applied.

During the survey interview it was particularly important to identify the methods that are most frequently applied in the process of multimodal education. As can be seen in Table 2, the methods of utmost importance are reflected in the following 5 categories: conversation, narrating a story, play, project, investigation, testing, experiment.

Table 2. The methods of multimodal learning to read and to write

\begin{tabular}{|c|c|c|}
\hline Category & Subcategory & Justifying statements \\
\hline \multirow[t]{4}{*}{ Methods } & Conversation & $\begin{array}{l}\text { " }<\ldots>\text { to enable a child to better } \\
\text { understand all this, it is necessary talk with } \\
\text { a child, to discuss what } \mathrm{s} / \text { he has done or } \\
\text { learnt and whether s/he has succeeded or } \\
\text { not }<\ldots>\text { ". }\end{array}$ \\
\hline & Narrating a story & $\begin{array}{l}\text { "there is a wish to mark the created story } \\
\text { on the sheet of paper: to draw it, to mark } \\
\text { symbolic signs and to tell it }<\ldots>\text { ". }\end{array}$ \\
\hline & Play & $\begin{array}{l}\text { " }<\ldots>\text { it may appear from aside that we } \\
\text { are only playing but playing also includes } \\
\text { learning". }\end{array}$ \\
\hline & Projects & $\begin{array}{l}\text { "We implement projects: in smaller or bigger } \\
\text { groups, including kindergarten community as } \\
\text { well". }\end{array}$ \\
\hline & $\begin{array}{l}\text { Investigation, } \\
\text { testing, } \\
\text { experiment }\end{array}$ & $\begin{array}{l}\text { "We are constantly engaged in investigation } \\
\text { and experimenting in the group }<\ldots>\text { ". }\end{array}$ \\
\hline
\end{tabular}

The analysis of data accumulated during the interview with teachers allowed distinguishing the qualitative category: activities and the characteristic subcategories: activities initiated by the teacher, child's spontaneous activity, additional activities (Table 3).

It is written in the General Curriculum of Pre-primary Education (2014) that the educational environment has to contain various means that could be used by children to imitate writing, to copy letters or combination of letters, to draw ornaments, to colour, to cut (big sheets of paper, various writing and colouring means, crayons, etc.).

Therefore, during the research attempts were made to identify the means used by the teachers most frequently while teaching children to read and to write. The results are shown in Table 4. 
Table 3. The activities, where children's multimodal learning to read and to write occur

\begin{tabular}{|c|c|c|}
\hline Category & Subcategory & Justifying statements \\
\hline \multirow[t]{3}{*}{ Activities } & $\begin{array}{l}\text { Activities } \\
\text { of reading } \\
\text { and writing } \\
\text { initiated by } \\
\text { the teachers }\end{array}$ & $\begin{array}{l}\text { Agile games: } \\
\text { "< . . > I hang some letters and children jumped } \\
\text { trying to reach the letter of their name and say it". } \\
\text { "< . . > we play hunting of letters". } \\
\text { Play with sand, water, snow: "We make letters in the } \\
\text { snow by foot and name them". } \\
\text { Nature research: "We make attempts to envisage the } \\
\text { contours of letters in the trees, recognise, name and } \\
\text { create new words". } \\
\text { Mind map: "Children in my group like mind maps very } \\
\text { much". } \\
\text { Artistic activities: "Colouring of letters, applications, } \\
\text { decorations < ...". } \\
\text { Activities with ICT: “ < ...We frequently use an } \\
\text { interactive board. We write letters, words, short } \\
\text { sentences on the computer screen }<\ldots . .>\text { ". }\end{array}$ \\
\hline & $\begin{array}{l}\text { Spontaneous } \\
\text { child's } \\
\text { activity of } \\
\text { reading and } \\
\text { writing }\end{array}$ & $\begin{array}{l}\text { Constructive games: "They create towers of letters". } \\
\text { Agile games: "< } \ldots>\text { throw a ball and think of } \\
\text { words". } \\
\text { Modelling: "Children like to mould letters from clay } \\
\text { and play dough". } \\
\text { Play with sand and waters: " }<\ldots>\text { children like to } \\
\text { write with colourful foam on the water". } \\
\text { Play with objects in the environment: "Looking at the } \\
\text { contours of the letters in a certain object the child } \\
\text { makes attempts to trace the letter with his/her finger } \\
\text { and give the name to it". } \\
\text { Activities with books and characters: "They "write" a } \\
\text { letter, create advertisements }<\ldots .>\text { ". }\end{array}$ \\
\hline & $\begin{array}{l}\text { Additional } \\
\text { activities }\end{array}$ & $\begin{array}{l}\text { Club of ceramics: " }<\ldots>\text { they like to put the letters } \\
\text { made from clay into combustion heater and then to } \\
\text { colour and decorate it". }\end{array}$ \\
\hline
\end{tabular}

Table 4. Educational means of multimodal learning to read and write

\begin{tabular}{|l|l|l|}
\hline Category & Subcategory & Justifying statements \\
\hline $\begin{array}{l}\text { Educational } \\
\text { means }\end{array}$ & $\begin{array}{l}\text { Traditional } \\
\text { means of } \\
\text { reading and } \\
\text { writing }\end{array}$ & $\begin{array}{l}\text { "To mould letters or their combinations from play } \\
\text { dough or clay". } \\
\text { "We cut letters from magazines, brochures and we } \\
\text { make collages". }\end{array}$ \\
\cline { 2 - 3 } & $\begin{array}{l}\text { Non- } \\
\text { traditional } \\
\text { means of } \\
\text { reading and } \\
\text { writing }\end{array}$ & $\begin{array}{l}\text { Sensor boxes: "Children like to pour bulk materials into } \\
\text { the dish of a form of certain letter and to name it". } \\
\text { Interactive boards: "Some children in my group may } \\
\text { not get distracted from the interactive board". } \\
\text { "We use a lot of use national materials: pebbles, shells, } \\
\text { walnuts, etc". } \\
\text { "The means made by myself are the most popular in my } \\
\text { work". }\end{array}$ \\
\hline
\end{tabular}


During the research attempts were made to identify environments, where children's multimodal learning to read and to write occurs, this can be seen in Table 5 .

Table 5. Educational environments of multimodal learning

\begin{tabular}{|c|c|c|}
\hline Category & Subcategory & Justifying statements \\
\hline \multirow[t]{5}{*}{$\begin{array}{l}\text { Educational } \\
\text { environments }\end{array}$} & Stimulating & $\begin{array}{l}\text { " }<\ldots>\text { has to stimulate the main senses of } \\
\text { children". }\end{array}$ \\
\hline & $\begin{array}{l}\text { Constantly } \\
\text { changing }\end{array}$ & $\begin{array}{l}\text { "The environment has to constantly undergo } \\
\text { changes". } \\
\text { "< }<\ldots \text { new activities have to be included all the } \\
\text { time". }\end{array}$ \\
\hline & $\begin{array}{l}\text { Evoking } \\
\text { curiosity }\end{array}$ & $\begin{array}{l}\text { "< }<>>\text { to evoke child's curiosity and to strengthen } \\
\text { motivation to explore". }\end{array}$ \\
\hline & Diverse & $\begin{array}{l}\text { " }<\ldots>\text { diverse and attractive environment to } \\
\text { every child." } \\
\text { "Diverse environment, which contains a lot of } \\
\text { educational means". }\end{array}$ \\
\hline & Targeted & "I know exactly why these things are in my group". \\
\hline
\end{tabular}

Multimodal learning to read and write essentially changes the old learning system, which is based on the direct teaching of children to decode the text on the paper and to learn to copy letters. Therefore, Table 6 represents a particularly important category: change in learning with the related characteristics: the process of learning: from uninteresting to interesting; motivation: from non-motivated to motivated; improvement of child's personal qualities: from closeness to full openness; emotion: from sad to joyful; faster learning: from slower to faster; free learning: from restricted to free; individualisation: from common to individual.

The content of the categories and subcategories distinguished in the previous tables shows that multimodal learning to read and write is a new way of learning, which brings a lot of benefit into the process of education. However, the survey of experts highlighted the difficulties most frequently encountered by teachers who use this way of learning. However, Koutsoupidou (2010) states that self-evaluation allows for objective defining of areas for growth and improvement. That is why, if the teacher has motivation, s/he is thought to acquire methodological knowledge.

During the expert survey, the teachers' preparations to work under conditions of multimodal learning were identified. As presented in Table 7, the following subcategories were distinguished: use of outdated and inappropriate methods; insufficient awareness of multimodal teaching; insufficient awareness of child's development; teacher's personal qualities. 
Table 6. The change in multimodal learning to read and to write

\begin{tabular}{|l|l|l|}
\hline Category & Subcategory & Justifying statements \\
\hline $\begin{array}{l}\text { Change in } \\
\text { learning }\end{array}$ & $\begin{array}{l}\text { The process of } \\
\text { learning: } \\
\text { from } \\
\text { uninteresting to } \\
\text { interesting }\end{array}$ & $\begin{array}{l}\text { "Learning < .. > as play, exploration, testing } \\
\text { rather than direct copying or reproduction". }\end{array}$ \\
\cline { 2 - 3 } & $\begin{array}{l}\text { Motivation: from } \\
\text { non-motivated to } \\
\text { motivated }\end{array}$ & $\begin{array}{l}\text { "< . . > is able to concentrate for a longer period } \\
\text { "They just immerse in activities". }\end{array}$ \\
\hline $\begin{array}{l}\text { Improvement of } \\
\text { child's personal } \\
\text { qualities: from } \\
\text { closeness to full } \\
\text { openness }\end{array}$ & $\begin{array}{l}\text { "They become more independent". } \\
\text { "Children are not afraid to experiment, to express } \\
\text { own feelings and to share experiences". }\end{array}$ \\
\hline $\begin{array}{l}\text { Emotion: } \\
\text { from sad to joyful }\end{array}$ & $\begin{array}{l}\text { "< .. > the mood of children increases } \\
\text { significantly, and it becomes elevated". }\end{array}$ \\
\hline $\begin{array}{l}\text { Faster learning: } \\
\text { from slower to } \\
\text { faster }\end{array}$ & $\begin{array}{l}\text { "The child learns to recognise letters without } \\
\text { realising and with ease". }\end{array}$ \\
\hline $\begin{array}{l}\text { Free learning: } \\
\text { from restricted } \\
\text { to free }\end{array}$ & $\begin{array}{l}\text { "Decrease children's anxiety and tension". } \\
\text { Individualisation: } \\
\text { from collective to } \\
\text { individual }\end{array}$ & $\begin{array}{l}\text { "We used to do everything together in the } \\
\text { worcise book. Now we try to make everyone } \\
\text { activities". }\end{array}$ \\
\hline
\end{tabular}

Table 7. Preparation of teachers

\begin{tabular}{|c|c|c|}
\hline Category & Subcategory & Justifying statements \\
\hline \multirow[t]{4}{*}{$\begin{array}{l}\text { Preparation } \\
\text { of teachers }\end{array}$} & $\begin{array}{l}\text { Use of } \\
\text { outdated and } \\
\text { inappropriate } \\
\text { methods }\end{array}$ & $\begin{array}{l}\text { "Up to now they have been working following, } \\
\text { according to them, proven methods, which turn out } \\
\text { to be inefficient". }\end{array}$ \\
\hline & $\begin{array}{l}\text { Insufficient } \\
\text { awareness of } \\
\text { multimodal } \\
\text { teaching }\end{array}$ & $\begin{array}{l}\text { " }<\ldots .>\text { have to be aware of the very specifics of } \\
\text { learning }<\ldots>\text { ". } \\
\text { "First of all theoretical foundations for applying } \\
\text { multimodal teaching are necessary". }\end{array}$ \\
\hline & $\begin{array}{l}\text { Insufficient } \\
\text { awareness } \\
\text { of child's } \\
\text { development }\end{array}$ & $\begin{array}{l}\text { " }<\ldots>>\text { have to understand that the child gets } \\
\text { familiar with the surrounding world through } \\
\text { independent exploration and involvement of his/her } \\
\text { all senses". }\end{array}$ \\
\hline & $\begin{array}{l}\text { Teacher's } \\
\text { personal } \\
\text { qualities }\end{array}$ & $\begin{array}{l}\text { "Firstly, teachers have to be inquisitive themselves } \\
\text { and not to be lazy to search for something } \\
\text { interesting". }\end{array}$ \\
\hline
\end{tabular}


The expert survey disclosed that the teachers gave rather diverse evaluations of their ability. They know the areas they are good at (e. g., creativity, flexibility, collaboration, etc.), but there are areas, where they encounter difficulties (lack of knowledge, insufficient awareness of methodology, its targeted presentation in the process of education) Such an objective self-evaluation created possibilities of determining directions for growth and improvement. It can be concluded if a teacher is motivated, s/he is likely to acquire methodological knowledge as well.

\section{Discussion}

The conducted research allowed disclosing the expression of multimodal learning in pre-primary education from various perspectives. Multimodal learning refers to learning that embraces senses and the child's personal experience and trials (Vasquez \& Felderman, 2012). The acquired data of empiric research disclosed that teachers working with pre-primary children also distinguished senses as a significant element of this learning. It should also be noted that pre-primary teachers also emphasised experience, exploration and play as significant parts of such learning.

Pursuing success in multimodal learning, it is important to highlight the methods employed for learning this way. The opinion of Shanahan (2013), who states that it is important to include all the possible ways and methods that contribute to activating the learning process, is worth attention. The data of expert survey showed that in their activities teachers tend to apply discussion, narrative, play, project, exploration, trial and experiment most frequently. According to the experts, these methods help a child to discover the joy of learning through curiosity.

Martinkienè (2004) states that children learn faster when their activities are directed to their own understanding and thinking or when they have to think of activities themselves. Pre-primary teachers emphasise that spontaneous activity of children, where they become creators and implementers of education, dominate in the educational process. However, teachers also emphasised the teacher-initiated activity, where she or he becomes not a teacher, who directly teaches the child to decode the text in the paper, but rather a creator of educational situations and a nurturer of written environment.

During the expert survey, the teachers' preparation to work under conditions of multimodal learning was identified. The results showed that teachers gave a rather controversial evaluation of their abilities: they are aware of areas where they are successful (e. g. creativity, flexibility, collaboration) but there are fields, where they encounter challenges (insufficient knowledge, incompetence in methodology and difficulties in its targeted 
application in the process of education). Carrington (2009) emphasises that self-assessment allows for identifying areas for growth and improvement. If a teacher possesses motivation, she or he is likely to obtain necessary methodological knowledge. Teachers have to discover their place and to understand their new role - to act as a mediator under changing conditions, to adapt knowledge to programmes of literacy development and to consider them in the discussion on abilities and principles of basic literacy.

\section{Conclusions}

The changing attitude towards learning to read and write obviously leads to strengthening of the tradition of multimodal learning in the Lithuanian kindergartens.

The working methods and means applied by teachers, which allow creating educational environments taking into consideration individual needs of every child environments, have been undergoing changes.

The conducted research revealed that pre-primary education groups provide children with favourable conditions for multimodal learning, which helps them not only to learnt to read and write faster but also develop other skills: fine motor skills, thinking, creativity, social skills, etc.

\section{References}

Baranova, J., \& Duoblienè, L. (2020). Filosofija vaikams ir multimodalus ugdymas: metodine priemoné [Philosophy for Children and Multimodal Education: a Methodological Tool]. Vilnius: Vilniaus universiteto leidykla.

Bearne, E. (2009). Multimodality, Literacy and Texts: Developing a Discourse. Journal of Early Childhood Literacy, 9(2), 156-187. https://doi.org/10.1177/1468798409105585

Carrington, V. (2009). From Blog to Bebo and Beyond: Text, Risk, Participation. Journal of Research in Reading. 32. 6-21. http://dx.doi.org/10.1111/j.1467-9817.2008.01378.x.

Gedutienė, R. (2008). Besiformuojančio raštingumo komponentu ir šeimos veiksniu squveika pereinant iš priešmokyklinio ị mokyklinį amžių. [Daktaro disertacija, Vilniaus universitetas]. [The Interplay of Emergent Literacy Components and Family Factors During the Transition from Preschool to School Age. [Doctoral dissertation, Vilnius University]]. Vilnius: Vilniaus universiteto leidykla.

Hassett, D., \& Schieble, M. (2007). Finding Space and Time for the Visual in K-12 Literacy Instruction. The English Journal, 97(1), 62-68. http://dx.doi.org/10.2307/30047210

McGuinness, D. (2005). Language development and learning to read: the scientific study of how language development affects reading skill. Cambridge, Massachusetts: The MIT Press.

Kitsiou, R., \& Kondyli, M. (2020). Intersections of Multimodal and Critical Literacy in Teacher Education: Multimodal Literacy Practices to Reconstrue Ideologically Charged Texts. International Journal of Literacies, 27(2), 1-16. https://doi. org/10.18848/2327-0136/CGP/v27i02/1-16 
Koutsoupidou, T. (2010). Self-Assessment in Generalist Preservice Kindergarten Teachers' Education: Insights on Training, Ability, Environments, and Policies. Arts Education Policy Review, 111 (3), 105-111. http://dx.doi.org/10.1080/10632911003626937

Kress, G., Jewitt, C., Ogborn, J., \& Tsatsarelis C. (2014). Multimodal Teaching and Learning: The Rhetorics of the Science Classroom. Bloomsbury Academic.

Martinkienè, G. (2004) Rašytinès kalbos ugdymo aktyvinimas. Monografija [Activation of Development of Written Language. Monograph]. Klaipėda: Klaipėdos universiteto leidykla.

Merkys, G., Augustinienė, A., Rupainienè, V., Lapienienė, A., Balčiūnas, S., ir Elijio, A. (2010). Iea Pirls 2006 antrinè duomeny analizé [Secondary Data Analysis of Iea Pirls 2006]. Retrieved from: https://www.smm.lt/uploads/lawacts/docs/624_43d66586657dc4f4c8238bfe10eecf23.pdf

Priešmokyklinio ugdymo bendroji programa [General Curriculum of Pre-primary Education]. (2014). Vilnius: Lietuvos Respublikos švietimo ir mokslo ministerijos Švietimo aprūpinimo centras. Retrieved from: https://www.smm.lt/uploads/documents/Prie\%C5\%A1 mokyklinio\%20ugdymo\%20bendroji\%20programa(3).pdf

Shanahan, L. (2013). Composing "Kid-Friendly" Multimodal Text. Written Communication, 30 (2), 194-227. https://doi.org/10.1177/0741088313480328

Vasquez, V. M., \& Felderman, C. B. (2012). Technology and Critical Literacy in Early Childhood. New York: Routledge. https://doi.org/10.4324/9780203108185 